\title{
非イオン性界面活性剤を用いた $\mathbf{O} / \mathbf{W}$ 型エマルションの電気伝導性
}

\author{
(1978 年 6 月 22 日受理)
}

野口駿・中沢文子・吉井恵子・故片田とし子*

非イオン性界面活性剂を用いた $\mathrm{O} / \mathrm{W}$ 型エマルションの電気伝導性を検討するため, 油相に流動パラ フィンを, 水相には脱イオン水をたは $0.01 \mathrm{~mol} / l \mathrm{KCl}$ 水溶液を, 界面活性剂としてはンルビタンー脂 肪酸エステル系のすのを用い, 種々の含水比のエマルションを調製し，低周波導電測定法により，10〜 $100^{\circ} \mathrm{C}$ 間で測定を行なった。従来用いられている分散系の電気伝導度に対する理論式は， $0.01 \mathrm{~mol} / \mathrm{l}$ $\mathrm{KCl}$ を用いたエマルション系について得た結果にきわめてよく適合した。

脱イオン水を用いたエマルション系では，その分散媒の伝導度が界面活性剤の含有量に比例すると考 えるとやはり上記の理論式によく適合することがわかった。そこで, この系の伝導度は界面活性剤中の 電解質不純物に主としてよるものと仮定して検討したが，こうした仮定に基ついて脱イオン水を用いた 界面活性剤水溶液の伝導の挙動を十分に説明することはできなかった。

\section{1 楮 言}

著者らは食品中の水の結合状態の研究尚2)の一環として，モデ ル食品としてのェマルションの基礎的性質について検討してき だ)け。本報では非イオン性界面活性郕を用いた流動パラフィンー 水の $\mathrm{O} / \mathrm{W}$ 型エマルションの電気伝導性について述べる。

エマルションの䉓気伝道性については，誘電的性筫とともに花 非らがのすぐれた研究があり，分散系の理論的取り扱いについて は古くから多くの試みの゙がなれている。しかしながらこれら の裏付けとなる実験系としては不純物の影響を避け，㑚定を精密 に行ならための便法として伝導性の高い電解質水溶液を水相とし て使用しているために，もっと伝導性の低い領域についてそれら の適用性の検討は不十分であると思われる。ここではとくに電解 質を添加しない系の云導性について，電解筫添加系の結果を参考 にしながら考察を試みた。

\section{2 实験}

\section{1 試料の調䋿}

あらかじめ定められた量の流動パラフィンに所要量の界面活性 唷混合物（HLB=9.0 飞調整）を加え $80^{\circ} \mathrm{C}$ の水浴上で完全に混 合溶解させる。この混合物を水浴から扔らし，室温において木モ ミキサー（特殊機化工業型M型）によりかきまぜなからら、これに

* 共立女子大学家政学部, 101 東京都千代田区一ツ橋

1）中沢文子, 野口 駿, 家政誌, 29，140(1978).

2）中沢文子，高橋淳子，加藤昌子、野口 酸, 家政誌, 29 , 印刷中 (1978).

3）伊予田型子、野口 駿, 家政誌, 22, 424(1971).

4) S. Noguchi, Y.Maeda, Agric. Biol.Chem., 37, 1531 (1973).

5) T. Hanai, N. Koizumi, T. Sugano, R. Gotoh, KolloidZ., 171, 20(1960).

6）佐々木恒孝，花井哲也，光井武夫訳，“シャーマンエマ ルションの科学”, 朝會鼌店 (1971) p. 351 481.
あらかじめ $80^{\circ} \mathrm{C}$ に加温された眖イオン水または $0.01 \mathrm{~mol} / \mathrm{l} \mathrm{KCl}$ 水溶液を徐々に所定量加光る。室温に冷却するまでかきまぜを継 統すると $60^{\circ} \mathrm{C}$ 付近で $\mathrm{W} / 0$ 型から $\mathrm{O} / \mathrm{W}$ 型へ転相する。得られ たェマルションの重量を測定し，蒸発による水分損失を水の添加 によって補充し，所定の組成のエマルションを調製する。少なく とす 12 時間放置し，相分離を生じない安定なエマルションを測 定試料とし，一部は Karl Fischer 法によってその水分含量を娜 定する。

\section{2 界面活性剂混合物}

非イオン性界面活性㘊であるポり(オキシエチレン)ソルビタン モノオレフート（商品名 Tween 80) とソルビタンモノオレフー 卜（商品名 Span 80）とを53.3/46.7 の重量比で混合したるの を用いる。

その使用量はこれまでの経験()から，比較的安定なェマルショ ンを得るのに適した油量に対し $10 \%$ を基本とし，とくに安定な 系で約 7\%，油と水との比が 1:1 から大きくはずれる領域で $20 \%$ まで適宜增大した。これは全系に対して 1.9 8.3\% とな り，水相に対与る含有比は 2 50\% と全体的にきわめて高い。 したがって単純な水一油系のエマルションのほか界面活性郕の 影響を考慮して界面活性剂水溶液についても1.0４5\% の涨度範 团で検討した。したがって，これらの系においては界面活性郕の 水相に対する比はかなり高く，いずれの場合にも界面活性剤の CMC をはるか水上る。

\section{3 䉓筑伝等度の測定}

電気层導度測定には低周波湘定用の電導度計CDM-3型 (Radiometer $\mathrm{A} / \mathrm{S}$ 製) を用いる。適正な電極を用いることにより試料 の比伝導度が直接読みとれる。試料はプログラム自動調箢温度計

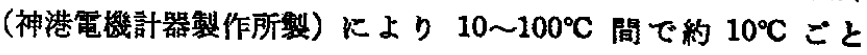
にそれぞれ 30 分間以上保持するように設定された办浴中で加温 され，試料温度と比伝導度とを同時仁記録する。 


\section{3 実 詇 結 果}

\section{1 水相として脱イオン水を用いた場合}

種々の含本比をむつ土マルションの比伝導度 $\kappa_{\mathrm{E}}$ を䋓対温度 $T$ の逆数に対してプロットしたすのが図1のE群である。ここで使 用された脱イオン水について同様な測定値は下方のCである。こ れらのE群の曲線は若干の例外を除いて含水星が $25 \%$ 以上の試 料については約 $70^{\circ} \mathrm{C}$ 以下，含水量か～ $20 \%$ 以下の試料について は約 $30^{\circ} \mathrm{C}$ 以下の温度範因内でたがいには涪平行な直線になって いるが，それ以上の温度範囲ではこの直線より若干下方へずれ る。これらの直線部分の上下の関係は含水比の順序とは必ずしも 一致しない。その傾向を明らかにするために $25^{\circ} \mathrm{C}$ に扰ける比伝 導度と含水比との関係を四 2 の $\mathrm{E}$ 亿示す。

これから明らかなよらに，含水比が滅少し界面活性㓣を含む油 相の割合が增大するにつれてェマルションの比伝導度は使用した 脱イオン水の値から增大し，含水比 $0.7 \sim 0.3$ の間でかなり広い 変動幅をるつが高值を示し，以後は油相の伝導度まで減少する。 この頵向恃由来を異にする脱イオン水を用いた別の試料系におい てるほぼ同様に認められる(比伝導度の值は若干異なる)。

図 3 のS群性用された非イオン性界面活性剤混合物の各種濃 度水溶液の比伝導度 $\kappa_{\mathrm{s}}$ の温度依存性を図 1 と同様に示したるの である。これから明らかなよらに䄪 50〜60 $0^{\circ} \mathrm{C}$ 以下の温度範囲内 で $\log \kappa_{\mathrm{S}} \sim 1 / T$ が注涪直線関係をるち，直線からのズレが認めら れる温度は含本量の低い試料注ど低い傾向がある。またとくに高

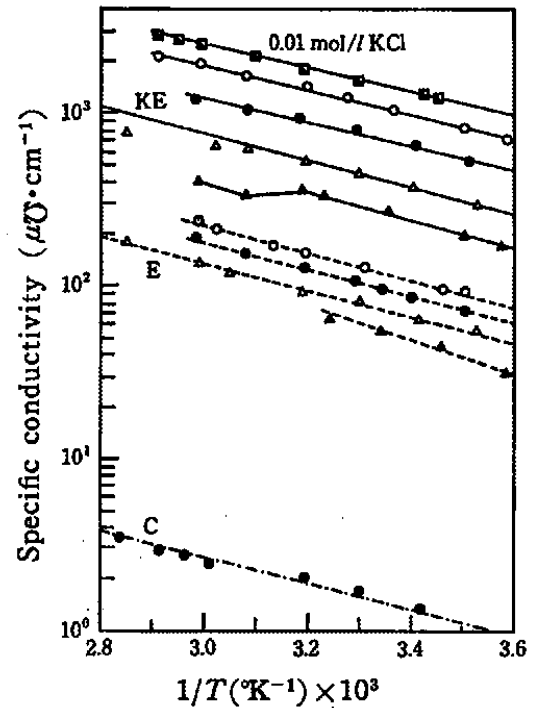

Fig. 1 Specific conductivity vs. $1 / T$ for deionized water-emulsion $(E), \quad 0.01 \mathrm{~mol} / l \mathrm{KCl}$-emulsion (KE) and deionized water (C)

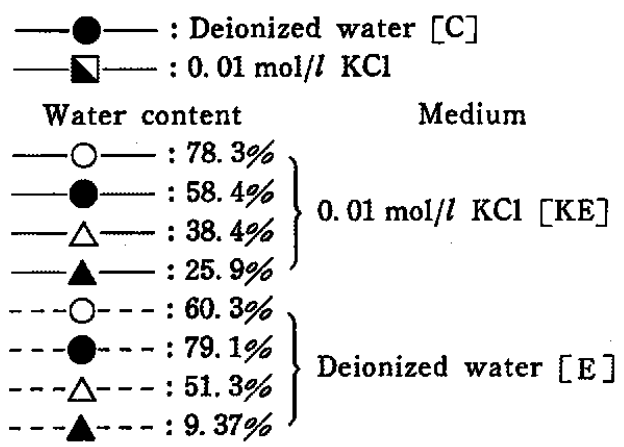

濃度でいらじるしい粘性を示した $45 \%$ 水溶液の場合を除いて， 界面活性郕の濃度の增大する順序にしたがって比伝導度が上昇す る。このよらすをエマルションと比較するために， $25^{\circ} \mathrm{C}$ の値に ついて図 2 の曲線 Sで示した。

\section{2 水相として $0.01 \mathrm{~mol} / \mathrm{l} \mathrm{KCl}$ 水溶液老用いた場合}

3.1 と同様に $0.01 \mathrm{~mol} / l \mathrm{KCl}$ 水溶液を水相として調製した

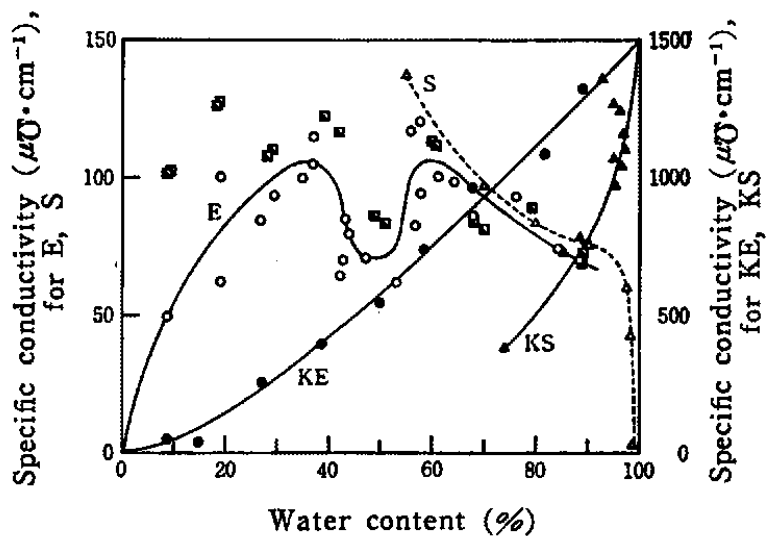

Fig. 2 Specific conductivity vs. water content at $25^{\circ} \mathrm{C}$ for emulsion (E), KCl-emulsion (KE), surfactant solution (S) and $\mathrm{KCl}$-surfactant solution (KS)

E, $\{Q$ : Observed

E, $\{\nabla$ : Calculated according to equation (4)

$S,---\triangle---$ : Surfactant solution

$\mathrm{KE}, \longrightarrow$ - $0.01 \mathrm{~mol} / \mathrm{l} \mathrm{KCl}$-emulsion

$\mathrm{KS},-\Delta \longrightarrow: 0.01 \mathrm{~mol} / l \mathrm{KCl}$-surfactant solution

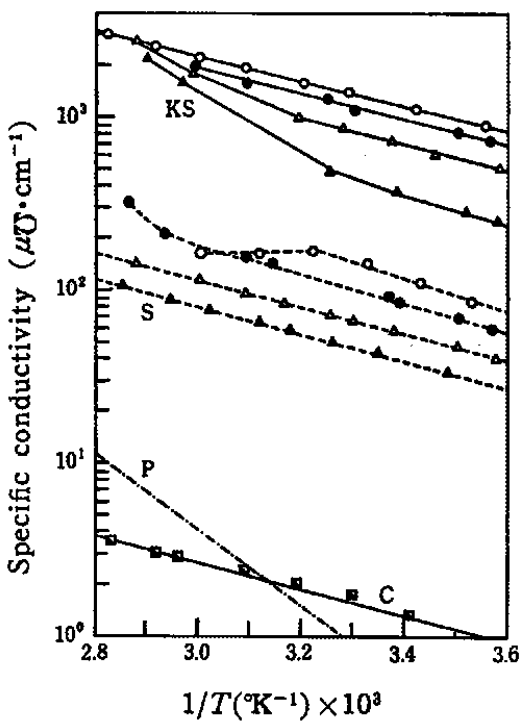

Fig. 3 Specific conductivity vs. $1 / T$ for two series of surfactant solutions

- KS : Surfactant solution in $0.01 \mathrm{~mol} / l \mathrm{KCl}$ solution

- - - S : Surfactant solution in deionized water Water content :

\begin{tabular}{|c|c|c|}
\hline & $\mathrm{KS}$ & S \\
\hline & $2.9 \%$ & $45 \%$ \\
\hline & $5.7 \%$ & $30 \%$ \\
\hline & $14.3 \%$ & $1.9 \%$ \\
\hline & $26.5 \%$ & $1.0 \%$ \\
\hline
\end{tabular}


$0 / \mathrm{W}$ エマルションの比伝尊度 $\kappa_{\mathrm{KE}}$ の温度依存性を図 1 の $\mathrm{KE}$ 群化, 界面活性剂溶液の比伝導度 $\kappa_{\mathrm{Kg}}$ の温度依存性图 3 の $\mathrm{KS}$ に, それらの $25^{\circ} \mathrm{C}$ に於ける比伝導度と含水比との関俰を四 2 の KE 和よぴ KS に示す。

\section{4 考察}

本実験に使用されたェマルションは影惴鏡観察の結果,ごく低 含水量のるのを除いて，ほぼ球形の，大きさを異にする油相を含 有していることが喼められた。したがって以下の考察においいて， これらのェマルションは表面を界面活性剤の親水基で取り囲まれ た油相（界面活性放を含む流動パラフィン）の球状粒子が水性分 散媒中に分散された系であり，むし，この系内に電気伝導に寄与 する不純物が存在するならば，それは界面活性㓣中に含まれてい たるので，それらはエマルション，あるいは水溶液の調製時に水 相に移行するものと仮定した。

\section{1 油相体栍の電気伝等度におよほす効果の推定}

球状粒子の分散系に和ける层導度に対する理論式として次式?

$$
\frac{\kappa-\kappa_{\mathrm{p}}}{\kappa_{\mathrm{m}}-\kappa_{\mathrm{p}}}\left(\frac{\kappa_{\mathrm{m}}}{\kappa}\right)^{1 / 3}=1-\phi
$$

$\kappa$ : 分散系の伝䢘度, $\kappa_{\mathrm{m}}$ : 分散媒の伝導度,

$\kappa_{p}$ : 分散相の伝導度, $\phi:$ 分散相の体䅺分率。

を用いると， $/ W$ ェマルションでは $\kappa_{\mathrm{m}} \gg \kappa_{\mathrm{p}}$ であるので近似的 K

$$
\frac{\kappa}{\kappa_{\mathrm{m}}}=(1-\phi)^{3 / 2}
$$

がなり立ら，実際によく適合することが確かめられている゙す。

本実験においても，まず伝導性の高い $0.01 \mathrm{~mol} / l \mathrm{KCl}$ 水溶液 を办相としたェマルション系 $\left(25^{\circ} \mathrm{C}\right)$ における(2)式の適合性に ついて検討した。

この系の調製にはすでに述べたように多量の界面活性都を便用 しており，その伝道度への寄与の可能性があるので，単に 0.01 $\mathrm{mol} / l \mathrm{KCl}$ 水溶液（比后酕度 $\kappa_{\mathrm{xCl}}$ ) と油相粒子のみの分散系と みなして(2)式を適用することには筑閣がある。そこで $\mathrm{KCl}$ 溶 液と界面活性剂溶液の伝導度には加成性がなり立つと仮定し $0.01 \mathrm{~mol} / l \mathrm{KCl}$ エマルション系の分散媒の比伝導度 $\kappa_{\mathrm{m}}$ としては $0.01 \mathrm{~mol} / l \mathrm{KCl}$ の比云導度 $\kappa_{\mathrm{KCl}}$ に界面活性剤による寄与分と して同一含水比の脱イオンホ-エマルション系の水相の比伝導度

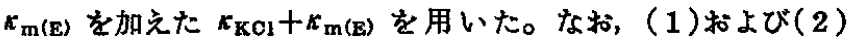
式のфは分散相の体積分率であるが，このエマルション系では正 確な体䅪分率を求めることができないので，分散相の重量分率 $\phi^{\prime}$ を， $\kappa_{\mathrm{m}(\mathrm{E})}$ としてはェマルション系の $\kappa_{\mathrm{E}}$ を近似的に使用し だ)

種々の含水比 $\left(1-\phi^{\prime}\right)$ の試料について上記の $\kappa /\left(\kappa_{\mathrm{Xcl}}+\kappa_{\mathrm{m}}\right)$ を $\phi^{\prime}$ に対してブロットしたのが図 4 の○印であり，（2）式の右辺 で申のかわりに $\phi^{\prime}$ を用いた結果が実線で示される曲線で，よく 一致していることがわかる。したがって，本実験におけるェマル ション系の油相の体積效果は (2)式で十分に評洒されらることが 明らかとなり，また近似的には体積分事として重量分率を代用し

7) R. E. de La Rue, C. W. Tobias, J.Electrochem. Soc., 108, 827(1959).

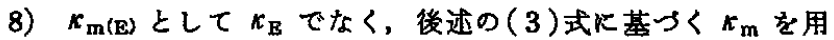
いても結果はほとんど变わらない。

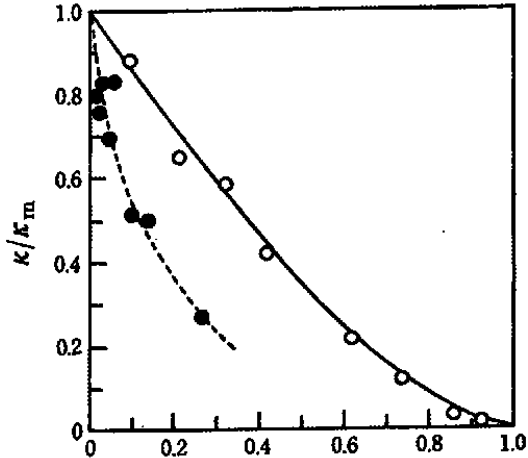

Weight fraction of disperse phase

Fig. 4 Conductivity of $0.01 \mathrm{~mol} / \mathrm{l} \mathrm{KCl}$-emulsion (KE) and surfactant solution (KS)

$\mathrm{O}:$ Observed value (KE)

: Observed value (KS)

_ : Calculated according to equation (2)

\section{らることるわかった。}

\section{2 脱イオン水のエマルション系に対する(2)式の道用}

この場合には分散媒の后導度 $\boldsymbol{\kappa}_{\mathrm{m}}$ として理論上は脱イオン皮の 伝導度を用いることになるが，図 1 から明らかなよ5にその值は きわめて低く，(2)式に代入してす実溉值とはまったく適合しな

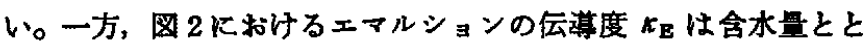
るに複雑な変化をしている。ここで最初の仮定のように，この非

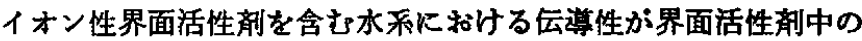
電解質不純物によるならば，その不純物濃度は界面活性剂の重量 $s$ K比例し，エマルション中の含水量 $w$ に反比例する。すなわ ち,

$$
\kappa_{\mathrm{m}}=A \frac{s}{w}
$$

これを(2)式と組み合わせ

$$
\kappa_{\mathrm{E}}=A \frac{s}{w}(1-\phi)^{3 / 2}
$$

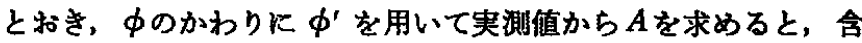
水比の小さな領城 $(s / w \geq 0.4)$ で若干小さくなる傾向があるが, $s / w=0.02 \sim 0.35$ においてはほ $4000 \mu$ に $\mathrm{cm}^{-1}$ となる。この值 を用い(4)式から $x_{\mathrm{E}}$ を求めると図 2 の四で示すように夷測値 にかなり近く，中央部での四みる忠実に再現されることがわか る。

この (3)式，したがって(4)式の適合については，界面活性刻 中の電解筫不純物が办相と油相とに分配されると考えることるで きる。しかしその場合には，Aは $s / w$ の堌大とともに减少する ことになり、この実験結果のようにAの一定性が成立する籍囲内 では電解質不純物の両相への分配は承相牌っており，実膯上 は水相のみに溶解していると考えて差し支えない。

また KCl 含有エマルション系の伝萮度はさきに示したように

$$
\kappa=\left(\kappa_{\mathrm{KCl}}+\kappa_{\mathrm{m}(\mathrm{E})}\right)(1-\phi)^{3 / 2}
$$

で示され， $\kappa_{\mathrm{KCl}}$ が約 $1500 \mu ひ \cdot \mathrm{cm}^{-1}$ でほぼ一定であるのに対 し， $\kappa_{\mathrm{m}(\mathrm{E})}$ は組成により変化するが約 $100 \mu \mho \cdot \mathrm{cm}^{-1}$ 程度で $\boldsymbol{\kappa}_{\mathrm{KCl}}$ の 1/10 以下であり, $\left(\kappa_{\mathrm{KCl}}+\kappa_{\mathrm{m}(\mathrm{E})}\right)$ に対しては $\kappa_{\mathrm{xCl}}$ が支配的 
であるので(4)式は遏用されない。

\section{3 界面活性郕水溶液の伝型性}

上記の $A$ は単位量の本相中に単位量の界面活性郕が存在する場 合の乕尊度であるから, 界面活性剂の当量公導度に比例した㑩を 示すはずである。このAが水相中の界面活性成濃度に関係なくほ とんど一定值を示すことは、この界面活性剂水溶液の示す伝導性 が強電解質に基つくくことを推定させる。本実験に使用された界面 活性剤は非イオン性のソルビタンー脂肪酸エステルおよびそのポ リ(エキレンオキシド)縮合体であり，そのオキシド部分がボリオ キソニウム型となってイオン化するきこともありうるが，これが 強電解質として電気伝導に大きく寄与しているとは考学難く，界 面活性俞中に磁量に存在する電解筫不純物が后導を支配している と考える方が妥当と思われる。

そこで，電解質不純物が存在するとして，その量を推定するた めに界面活性剂水溶液に種々の量の $\mathrm{KCl}$ を添加し, 比伝澊度の 增加のよらすから $\mathrm{KCl}$ 相当量として求めた。結果はかなりのば らつきを示し，推定精度はきわめて悪いが，界面活性剂 $1 \mathrm{~g}$ あた り $(5 \pm 2.3) \times 10^{-5} \mathrm{~mol}$ の電解質不純物が含まれることになっ た。

この平均推定量を用いて $\kappa_{\mathrm{S}}$ から䉓解筫不純物の当量层道度 $\Lambda$ を求め, 界面活性郕，したがって不純物の濃度に対してプロット すると図5のAのように濃度の増加にとるなってきわわて大幅な 减少が翟められる。この結果はさきに, エマルションの云導度に (4)式を適用して $A$ が界面活性用賑度とは经ぼ無関係に一定值を 示し，強電解質の寄与を推定させたこととまったく矛盾してい る。しかる，Aから不純物の当量伝導度 $A_{\text {st }}$ を求めると $80 \%$. $\mathrm{cm}^{2} \cdot \mathrm{mol}^{-1}$ となり，これは不純物の最る低濃度の $A$ とほぼ一致 ナるが, 高漊度での $\Lambda$ の値に対しては 10 倍以上にるなる。

このよらな矛盾の原因としては， $0.01 \mathrm{~mol} / l \mathrm{KCl}$ に界面活性 斉を溶解子ると，その量の増加ととるに伝尊度が低下し，この系 を溶液として扱らよりる，分散系のようにミセルによる水相の有 効体積の減少を考えることの必要性が示されることから，界面活 性放水容液系でる云導におよぽすミセルなどの体積の効果を考え ることができる。この効果をみるために $0.01 \mathrm{~mol} / l \mathrm{KCl}$-界面活 性刜溶液系の伝埒度 $\kappa_{\mathrm{KS}}$ を $\kappa_{\mathrm{KCl}}$ で除した值 $\kappa_{\mathrm{Ks}} / \kappa_{\mathrm{KCl}}$ を $\phi^{\prime}$ （ただし，只は界面活性成の重量分率）に対してブロットしてみ ると図4のように，この系に分散系の理論式(2)が成立するとし て予想される値よりいちじるしく低いことがわかる。このような ミセル溶液系に分散系の理諭式を適用することには問題もあろら が，上記の結果は，この溶液中の界面活性剂はその重量分率から 予想されるよりはるかに大きな空間を占めている傾向を示照する といえよう。すなわち，界面活性㨈がミセルを形成するさいに水 との相互作用が生じ，おそらくは界面活性剤分子の親水基の作用 によって水が不活性化され，自由水が減少するるのと解される が，この点についてはプロトンの緩和時間測定などによって詳緗 に検討の予定である。

こうしたミセルの体積增大效果は，脱イオン水による界面活性 都の水溶液においてる生じていると考えられるから， 4.3 で考察 した界面活性凧中の電解筫不純物に基つくくした当量公導度とし ては，その不純物たけを眖イオン水に溶解したさいに期待される

9) H. Wurzschmitt, Z. Anal. Chem., 130, 105(1950),
Concentration of surfactant $(\%)$

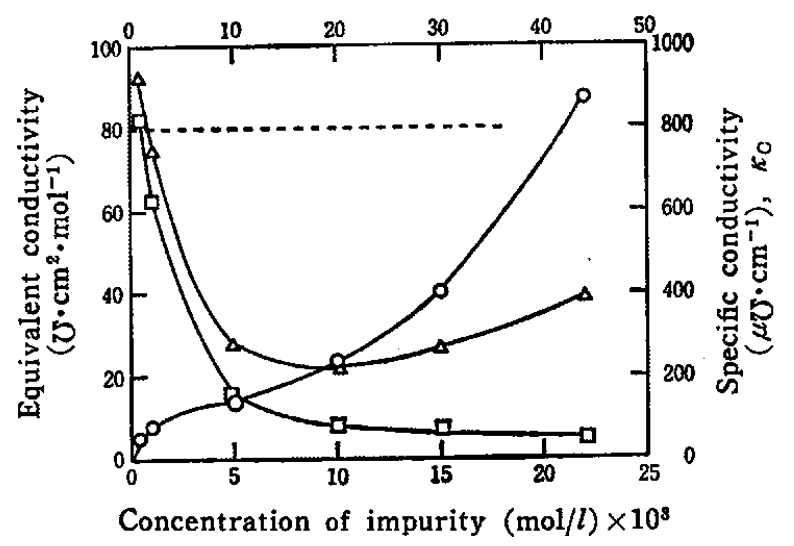

Fig. 5 Various conductivities of surfactant solutions

$O, \kappa_{\mathrm{S}}$ : Specific conductivity

ㅁ. $A$ : Equivalent conductivity (as to the impurity)

$\triangle, \Lambda_{\text {cor }}$ : Corrected equivalent conductivity (as to the impurity)

-.-, $A_{\text {est }}:$ Equivalent conductivity estimated from equation (4)

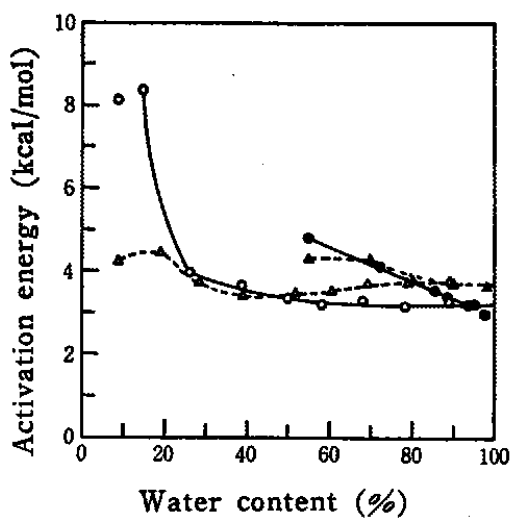

Fig. 6 Activation energies for conduction in emulsion, $\mathrm{KCl}$-emulsion, surfactant solution and $\mathrm{KCl}$-surfactant solution

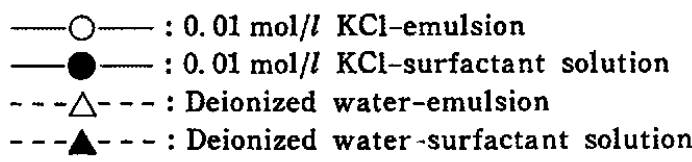

つぎの補正当量伝導度 $A_{\text {cor }}$ を算出してみた。

$$
\Lambda_{\mathrm{cor}}=\Lambda \times \frac{\kappa_{\mathrm{m}}}{\kappa_{\mathrm{Ks}}}
$$

このようにして求めた $\Lambda_{\text {cor }}$ を対応する界面活性剂（不純物）濃 度に対してブッットすると図5のよらになる。この $\Lambda_{\text {cor }}$ は $\Lambda$ りも濃度依存性がかなり小さくはなるが, それでも高濃度側では $\Lambda_{\text {est }}$ の $1 / 2 \sim 1 / 3$ 程度に過ぎない。

このように，脱イオン水のエマルションの伝递度は単にその水 相の伝導度が ( 3 )式のように水中の界面活性剂濃度に比例すると 考えれば分散系の理論式が適合されるにるかかわらず，実䟢の界 面活性剂水溶液の単位濃度あたりの公導度は濃度の增大とともに いちじるしく減少し（3）式はまったくなり立たない。したがって 界面活性剤水溶液系ではミセルなどの存在によって，伀導に有効 な水相容積がその構成比から推定されるよりはるかに減少してい 
ると考えられ，その原因は水和相にあると思われる。一方，ェマ ルション禾ではこうした水和相に基づく体積效果を考虑しないで る実際上差し支えないことを説明するにはつぎのような仮定を必 要とする。

（a）エマルション系ではかなりの界面活性剤が油相中に取り 込まれ，水と有効な接触をすることのできる界面活性剤の数が水 溶液系の場合よりいちじるしく小さいなどの理由から，有效な水 相の容積はあまり変化せずに，電解質不純物たけがほぼ完全に水 相に移行する。あるいは,

（b）この系の電気伝尊は電解質不純物によるのではなく，界 面活性珴と他の構成成分，おそらくは水との相互作用によって生 じる， $\mathrm{KCl}$ 系とは異なる伝尊機棈による。

これらに関連して, 四 1 および図 3 の直線とみなせる温度範囲 (皮むに $10 \sim 30^{\circ} \mathrm{C}$ ) について求めた伝導の活性化エネルキー（図 6) は，脱イオン水系の方が $0.01 \mathrm{~mol} / l \mathrm{KCl}$ を含む系よりわず かに高い㑯向にあることを示すが，これから明瞭な結論をらるこ とはできない。また，このエマルション系の水ーブロトンの緩和
時間の測定 ${ }^{10}$ から，界面活性都 $1 \mathrm{~g}$ あたりの束紏水量を推定し ているが，その詳細については別に報告の予定である。

なお，水口ら ${ }^{11) 129}$ はゼラチンなどの高分子物質の電気伝導度を 湘定して，これらの高分子物質を溶解すると伝導性が低下するこ とから，水が束䋠され，電解質に対し解離作用をるたない状㦔に 変化するためであるとしている。しかし，そこに認められている 籁囲内で自由水と考えている水中の電解質浱度の変化はたかたか 数倍程度であり，それによって電離がいちじるしく影響を受ける とは考えられず,むしろ，(2)式で取り扱ったような不良導体相 の体積効果を考える方が合理的であるよらに思われる。

いずれにしても，本実験の結果の解釈には水和の問題を含めた 解釈が必要であり，この点についてはさらに検討の予定である。

本研究を行ならにあたり，近藤惠美子，元島らん子，山中史 子，工藤八千代さん莘の協力を得ました。深く感謝します。

10）野口 酸, 中沢文子, 吉井恵子、未発表.

11）水口 純，高槅正昭，相沢益男，日化，91，723(1970).

12）水口 純, 高橋正昭, 相沢益男, 日化, 91，961(1970).

\title{
Electric Conduction of Oil-in-Water Emulsions Stabilized with Nonionic Surfactants
}

\author{
Shun Noguchi, Fumiko Nakazawa, Keiko YoshiI \\ and (the late) Toshiko Katada \\ Kyoritsu Women's University; Hitotsubashi, Chiyoda-ku, \\ Tokyo 101 Japan
}

Electric conduction of oil-in-water emulsions stabilized with nonionic surfactants was investigated. The emulsions were prepared by using liquid paraffin as the oil phase, deionized water or an $0.01 \mathrm{~mol} / l \mathrm{KCl}$ aqueous solution as the water phase, and a mixture of poly(oxyethylene) sorbitan monooleate and sorbitan monooleate as the emulsifying agent, respectively. Temperature dependence of the electrical conductivity was measured between 10 and $100^{\circ} \mathrm{C}$ by means of a low-frequency conductometry.

For the emulsions prepared with an $0.01 \mathrm{~mol} / l \mathrm{KCl}$ solution, a theoretical equation proposed by de La Rue et al. for the conductivity of a disperse system was proved to hold well. With the assumption that the electrical conductivity of the emulsions prepared with deionized water is proportional to the amount of surfactant contained, the theoretical equation mentioned above was also found to interpret the conductive behavior of the emulsion of deionized water well. The assumption made, however, was not proper for the interpretation of the conductive behavior of the surfactant solutions, which gave much lower conductivities than those expected from the assumption. 